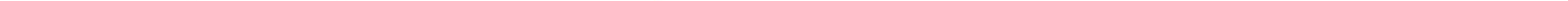




\section{Kisah Investasi Dan Aktualisasi Diri Mahasiswa Manajemen Universitas Islam Syekh-Yusuf}

REVIEWER

BAMBANG AFRIADI, S.Pd., M.Pd

SUGENG LUBAR PRASTOWO, S.T., M.M

ISBN : 978-623-9 I I I 7-0-0

\section{EDITOR}

RIA KURNIAWATI, S.Pd., M.Si

ILHAM AJI PANGESTU, SH., M.H

BAGUS MANUNGGAL, S.ST., MM

Desain Layout

Prof Ngopi

Desain Sampul

Prof Ngopi

PENERBIT: PT. Jamus Baladewa Nusantara

Cetakan Pertama, Juli 2019

\section{REDAKSI}

Alamat: Perumnas Terluk Jambe Karawang Perumnas Terluk Jambe, Blok H 64, Rt. 006/rw 009, Desa Sukaluyu, Kec. Teluk Jambe Timur, Kab. Karawang, Jawa Barat Karawang. Telp. 0812.1219.3335. e-mail: sg.lubar@gmail.com

Hak cipta dilindungi undang-undang

Dilarang memperbanyak karya tulis ini dalam bentuk dan dengan cara apapun tanpa ijin tertulis dari penerbit.

@ PT. Jamus Baladewa Nusantara 


\section{KATA PENGANTAR}

Puji syukur kami panjatkan kehadirat Tuhan Yang Maha Esa (Allah SWT) atas segala rahmat dan hidayah yang telah diberikan kepada kita semua, sehingga karya pertama mahasiswa dan mahasiswi Prodi Manajemen Universitas Islam Syekh-Yusuf (UNIS) Tangerang pada kelas 6B, 6C dan Kelas Loncatan untuk Mata Kuliah Bahasa Indonesia Tahun 2019 dapat terealisasikan dan terdaftar di Perpustakaan Nasional dan mendapatkan ISBN, karya ini disusun sebagai motivasi teman-teman mahasiswa dan mahasiwi untuk tetap berkarya.

Buku ini memuat sejumlah kisah mahasiswa dan mahasiswi Prodi Manajemen Universitas Islam Syekh-Yusuf (UNIS) Tangerang pada kelas 6B, 6C dan Kelas Loncatan untuk Mata Kuliah Bahasa Indonesia Tahun 2019. Oleh karena itu, dalam kesempatan ini perkenankan kami mengucapkan terima kasih kepada:

I. Dr.H. Hadi Suharno, SE., MM (Dekan FEB UNIS)

2. Dr. Joko Rianto, S.E., M.M (Wakil Dekan I FEB UNIS)

3. Parlindungan Dongoran SE.,M.Si (Wakil Dekan 2 FEB UNIS)

4. Zain Zainuddin, SE.,MM (Ketua Program Studi Manajemen)

5. Anna Sofia Atichasari, SE.,M.Si.,CMA (Ketua Program Studi Akuntansi)

6. Ibu Ria Kurniawati, S.Pd., M.Si, bapak Bagus Manunggal, S.ST., MM, bapak Ilham Aji Pangestu, SH., M.H, dan Sugeng Lubar Prastowo, S.T., M.M yang telah meluangkan waktu, tenaga, dan pemikirannya demi terealisasinya karya ini

7. Tak lupa kami sampaikan terima kasih kepada PT. Jamus Baladewa Nusantara yang telah memfasilitasi terbitnya buku ini.

8. Dan juga segenap dosen FEB Universitas Islam Syekh-Yusuf.

Semoga buku ini dapat memberi manfaat bagi kita semua, untuk kepentingan pengembangan ilmu pendidikan. Selanjutnya, diharapkan juga dapat menjadi referensi bagi upaya peningkatan kualitas pendidikan.

Tangerang, Juli 2019

Dosen Pengampu

Bambang Afriadi 


\section{DAFTAR ISI}

\begin{tabular}{|c|c|c|}
\hline No & Judul & Halaman \\
\hline I & Cinta Sejatiku Suamiku & $\mathrm{I}$ \\
\hline 2 & Rajeg Desa Kecil Sejuta Cerita & 6 \\
\hline 3 & Harapan Dan Semangat & $\mathrm{II}$ \\
\hline 4 & Diaryku & 16 \\
\hline 5 & Kisah Singkat Hidupku & 21 \\
\hline 6 & Terjebak Di Dunia K-pop & 26 \\
\hline 7 & Sekolah Di 2 Kota & 31 \\
\hline \multirow[t]{2}{*}{8} & Aku Bukanlah Pengarang Cerita Yang Baik, Tapi Aku Dapat & 36 \\
\hline & Menceritakan Kehidupan Ku & \\
\hline 9 & Keceriaan Di Kampus & 41 \\
\hline 10 & Kisah Laki-Laki Tulen & 45 \\
\hline II & Belajar Dan Belajar Untuk Mencapai Kesuksesan & 50 \\
\hline 12 & Momen-Momen Yang Tidak Terlupakan & 54 \\
\hline 13 & Sebuah Perjalanan Kisah Cinta & 59 \\
\hline \multirow[t]{2}{*}{14} & Sebuah Pengalaman Yang Telah Diberikan Oleh Kampus & 64 \\
\hline & Universitas Islam Syekh-Yusuf Tangerang & \\
\hline 15 & Kisah Dari Beberapa Hari Lagi Usia 21 Tahun & 69 \\
\hline 16 & Cerita Awal Memasuki Kuliah Di UNIS & 73 \\
\hline 17 & Menjadi Mahasiswa & 77 \\
\hline 18 & Kisah Selama SMA Hingga Kuliah & 82 \\
\hline 19 & Sehari-Hari & 87 \\
\hline 20 & Jatuh Hati pada Kakak Kelasku & 92 \\
\hline 21 & LDKM Fakultas Ekonomi & 97 \\
\hline
\end{tabular}




\begin{aligned} No & \multicolumn{1}{c}{ Nama Penulis } \\ I & Aan Diana \\ 2 & Abdul Rahman Sidiq \\ 3 & Ahmad Shamsil Yaqin \\ 4 & Aida Safitri \\ 5 & Alfira Maharani \\ 6 & Amanina Nada Fairuz \\ 7 & Amelia Maresti \\ 8 & Anisah Novianti \\ 9 & Chandra Pranadipta Wiguna \\ 10 & Dewi Yulia \\ II & Fika Safitri \\ 12 & Hardianti \\ 13 & Hildawati \\ 14 & Inayah Sufiani Jatnika \\ 15 & Krismonia \\ 16 & Lola Pitaloka \\ 17 & Miftahul Anwar \\ 18 & Nurrakhmah Komalasari \\ 19 & Wahyudi Tanjung \\ 20 & Widya Pristiyaningrum \\ 21 & Yuniati Permata Wulandari \end{aligned}

Pada buku ini judul buku dan nama penulis sengaja tidak sesuai dengan urutan. Hal ini sesuai kesepakatan reviewer dan penulis, yang berkenaan dengan privasi penulis.

Ada sebuah kata dari sang bijak:

\section{"Bila kamu bukan anak raja, juga bukan anak ulama besar, maka menulislah (Al Ghazali)."}

